\title{
MEDIA POLITIK: SARANA PENDONGKRAK ELEKTABILITAS SEBAGAI STRATEGI PEMENANGAN PEMILU
}

\author{
Gusti Yasser Arafat \\ Fakultas Dakwah dan Ilmu Komunikasi, UIN Antasari, Banjarmasin, Indonesia \\ Email: gyasserarafat@gmail.com \\ Nur Alfa Rahmah \\ Fakultas Tarbiyah dan Keguruan, UIN Antasari, Banjarmasin, Indonesia \\ Email: Nurulfarahmah@gmail.com
}

\begin{abstract}
Media cannot be separated from human lives, especially in digital era (IR 4.0); they aim to spread information to public and as a consequence affect public perspectives and behavior. From this point, media eventually functions to drive public opinion which in politics determine voter's choices; which in other words, media become political tools. Utilization of media for politics is significant as a winning strategy to increase electability of candidates and parties.
\end{abstract}

KEYWORDS Media; Politic media; digital era; public opinion; voter; candidate; parties; electability; winning strategy.

\section{Pendahuluan}

Suasana perpolitikan di Indonesia menjadi sangat berbeda pasca runtuhnya rezim orde baru di bawah pimpinan presiden Soeharto. Rezim yang dipandang sebagai pemerintahan otoriter yang mengekang kebebasan beraspirasi dan semena-mena menggunakan atau menyalahgunakan kekuasaan. Proses demokrasi tentu saja tidak dapat berjalan. Menurut Susilastuti (2000) dalam ranah media, pers menjadi terbungkam terbelenggu, pers berada dibawah komando penguasa, pers tidak beda dengan antek penguasa yang hanya menyebarkan informasi yang menguntungkan dan memihak penguasa saja. Jika ada yang melanggarnya jawabanya adalah bredel atau cabut izin produksinya. Sekarang zaman sudah berbeda dengan beralihnya kekuasaan ketika semangat reformasi menggelora merombak tatanan yang dulu dinilai serong dari demokrasi dan berkebebasan.

Kebebasan untuk menyebarkan informasi yang luar biasa masifnya dan kadang melampaui tatanan norma dan aturan bersambut dengan keleluasaan 
khalayak ramai dalam memperoleh informasi.(Idy Muzayyad, 2012) Melalui berbagai jalur media, massa dapat dengan mudah mengakses informasi yang diinginkannya dan informasi yang menerpanya (tidak selalu diinginkannya). Jumlah pengkases media kian hari juga semakin bertambah, informasi dapat dengan mudah dan cepat masuk hingga ke ranah-ranah private lewat berbagai media sosial dan portal-portal berita di internet. Alasan ini lah yang mendasari banyak kandidat dan partai-partai untuk melancarkan iklan-iklan politiknya melalui media (politik) sebagai sarana untuk meningkatkan daya elektabilitasnya. Media kemudian digunakan oleh aktor politik dan pihak tertentu (misalnya penguasa) untuk kepentingannya. (Hermin Indah Wahyuni, 2000)

\section{Hasil Penelitian dan Pembahasan \\ Politik dalam Media di Demokrasi Awal yang Tertatih}

Pers selain sudah bebas juga kaya akan nuansa politik dan ini menjadikan permasalahan baru dalam proses demokrasi ini. Media mempunyai peranan penting dalam menyuarakan, menyebarkan, meyakinkan dan mengarahkan khalayak untuk membentuk opini, memilih, menentukan, bertindak atau berbuat sesuatu.(Bagir Manan, 2012) Di lain pihak khalayak yang baru lepas dari pasungan sitem otoritarianisme sangat haus akan keingintahuan disegala aspek kehidupannya, termasuk aspek politik (demokrasi). Sadar akan hal ini media tak pelak lagi dimanfaatkan oleh politisi-politisi untuk usahanya meraih kekuasaan.

Media elektronik dan media cetak juga media online/sosial (internet) dirambah oleh iklan-iklan politik yang mengusung suatu partai atau kandidatkandidat, mulai dari pemilukada, perwakilan rakyat di daerah (DPRD Tingkat I dan II) dan di pusat (DPR) juga DPD hingga presiden dan wakilnya. Politik adalah sarana untuk mencapai kekuasaan atas suatu wilayah beserta yang termaktub di dalamnya untuk dapat diperintah sesuai peraturan yang disetujui. Karena alasan ini lah politik menjadi magnet bagi setiap orang untuk dapat "memainkannya" dengan cerdik, pandai dan terkadang juga licik dan tak berperikemanusiaan seperti pada era pemerintahan yang kejam dan keji.

Iklan merupakan metode mempengaruhi jalan pikiran konsumen dengan tujuan agar konsumen tersebut tergiur untuk menentukan tindakan yang berkesesuaian dengan si pemesan iklan tersebut terhadap media.(Rhenal Kasali, 1995) Iklan dapat dimengerti sebagai salah satu bentuk komunikasi yang terdiri atas informasi dan gagasan tentang suatu produk yang ditujukan kepada khalayak secara serempak agar memperoleh sambutan baik. Iklan berusaha untuk memberikan informasi, membujuk dan meyakinkan.(Sudiana, 1986) Periklanan merupakan bauran pemasaran, yaitu salah satu bentuk khusus komunikasi untuk memenuhi fungsi pemasaran. Untuk dapat menjalankan fungsi pemasaran, maka yang dilakukan harus lebih dulu dari sekedar memberi informasi pada khalayak. Para ahli mengungkapkan bahwa iklaan merupakan bentuk komunikasi yang sungguh-sungguh dapat merasuk dalam satu atau banyak hal, mencapai setiap 
lapisan dan anggota masyarakat. Iklan dapat membantu mencapai hampir setiap tujuan komunikasi. Iklan merupakan alat yang sangat berpengaruh untuk membangkitkan kesadaran untuk menentukan pilihan.

Unsur penting yang memadu dalan suatu iklan adalah kata dan gambar (unsur lainnya adalah musik atau suara back ground untuk media elektronik seperti televisi atau radio atau juga yang paling masif di internet/media sosial. Melalui kata dan gambar akan didapat bentuk ekspresi komunikasi yang efektif. Komunikasi yang efektif sangat ditentukan oleh perpaduan antara kata dan gambar. Karena dengan gambar proses komunikasi menjadi lebih sederhana dan menjadi lebih efektif.(S. L. Tubbs dan Moss S., 2003) Pada iklan-iklan yang dapat dilihat sekarang ini semakin banyak kemajuan ada yang mengurangi atau menambah unsur-unsur lain sehingga bentuknya bahkan lebih menarik dan maknanya semakin sampai ke khalayak. Misalnya dalam hal kata-kata, kata-kata dipilih dan diolah sedemikian rupa sehingga lebih menarik perhatian khalayak dan juga lebih mudah diingat dikepala mereka.

\section{Seluk-Beluk Iklan Politik}

Iklan politik, beberapa hal tidak berbeda dengan iklan-iklan produk komersil lainnya, mereka sama-sama menawarkan produk dan merayu khalayak untuk dapat dipengaruhi dengan kata-kata, gambar-gambar dan unsur-unsur lain. Tujuan iklan politik tak lain adalah mempersuasi dan memotivasi pemilih untuk memilih kandidat tertentu. Untuk mencapai tujuan tersebut iklan politik tampil impresif dengan senantiasa mengedepankan informasi tentang siapa kandidat, apa yang telah kandidat lakukan. Isi Iklan politik senantiasa berisi pesan-pesan singkat tentang isu-isu yang diangkat kualitas kepemimpinan, kinerja dan pengalamannya. Iklan politik, sebagaimana dengan iklan produk komersial yang pandai menggugah indera manusia.

Seperti yang disebutkan oleh Linda Lee Kaid dalam Andika Mongilala bahwa iklan politik adalah proses komunikasi dimana seorang sumber (biasanya kandidat dan atau partai politik) membeli atau memanfaatkan kesempatan melalui media massa guna meng-exposure pesan-pesan politik dengan sengaja untuk mempengaruhi sikap, kepercayaan dan perilaku politik khalayak.

Para politisi berupaya keras untuk meraih simpati dan dukungan dari khalayak luas dengan cara mempengaruhi mereka melalui iklan-iklan politik yang dimuat dalam pelbagai media. Iklan-iklan politik berisikan pesan-pesan politik yang biasanya diselubungkan dalam pesan-pesan sosial sehingga menarik perhatian atau bahkan rasa iba sehingga menggugah rasa untuk mendukung salahsatu kandidat atau partai tertentu. Iklan politik adalah bagian dari kampanye, bahkan metode ini labih dominan sekarang ini, mungkin karena dirasa lebih efektif dan efisien dibanding dengan metode kampanye konvensional yang cukup melelahkan dan bias jadi menguaras bajet lebih banyak jika harus menjangkau 
wilayah yang begitu luas juga ketika harus berhadapan dengan wilayah yang kemungkinan merupakan basis kandidat lawan. Kampanye melalui iklan menjadi pilihan yang diambil oleh hampir semua kandidat dan partai yang mempunyai cukup dana untyuk melakukannya. Kampanye adalah salah satu bentuk komunikasi, sebuah komunikasi politik yang komunikatornya adalah para politisi atau partisipan atau orang-orang yang ditunjuk dan bekerja pada lembaga atau partai atau yang behubungan dengan upaya pemenangannya. Kampanye adalah perjuangan dalam bnentuk persuasif untuk mempengaruhi dan menajak orangorang yang belum mnegetahui sama sekali atau masih ragu menentukan pilihannya agar kemudian bersedia bergabung dan mendukung pihak tertentu.

Dapat dilihat sekarang iklan-iklan politik semakin banyak menghiasi media massa kita. Perang iklan pun sudah dan sedang terjadi. Umumnya iklan dimaksud diisi oleh partai-partai politik, kandidat bakal calon-calon presiden, dan para calon legislatif. Model dan modusnya pun bervariasi. Tetapi kebanyakan bermuatan sebatas pencitraan diri agar dipilih dan didukung rakyat pada saat pemilu nanti. Hal itu terlihat dari isi iklan. Partai pemerintah dengan hebat menampilkan keberhasilan pemerintah sebagai headline dari iklan politiknya. Sementara partai-partai oposisi tampil dengan ejekan atas beberapa atau bahkan semua tentang kebijakan pemerintah yang dinilai tidak memihak rakyat.

Beberapa iklan ada yang menjual masalah-masalah sosial yang sedang terjadi dan terasa bagi masyarakat, seperti kemiskinan, pengangguran, daya beli rakyat, kebutuhan pokok rakyat luas, keadilan hukum, keamanan, dan kesatuanpersatuan bangsa. Sementara pada sisi program, tema utama iklan juga cenderung bervariasi. Ada yang berjanji untuk mengembangkan rasa cinta pada produk sendiri, membela petani, penyediaan lapangan kerja, harga bahan pokok yang murah.

Selain itu, terdapat juga model iklan yang juga menampilkan prestasi kandidat secara perseorangan yang sebelumnya bahkan orang-orang tidak mengetahuinya atau juga memang benar-benar tidak ada prestasi. Materi iklan pun menjadi pergunjingan politik. Iklan yang pada dasarnya ditujukan untuk menambahkan rasa simpatik dari masyarakat pemilih, berubah menjadi ajang ejek-mengejek dalam media dan ditonton oleh masyarakat. Akhirya opini yang terbentuk di masyarakat adalah semua yang ditampilkan dalam iklan politik tersebut menjadi bukti bahwa para kandidat mempunyai tabiat saling sikutmenyikut. Secara tidak langsung media memberikan ruang bagi pencontohan yang tidak baik. Memang iklan punya cara pandang dan pendekatan tersendiri. Dan cara pandang itu hanya dimiliki oleh si pemproduksinya. Tapi yang terkadang dilupakan adalah ketika iklan sudah sebarkan ke publik, iklan tersebut sudah menjadi milik publik. Rakyat pun bebas menyampaikan pujian dan juga kritik kepadanya. Umpan balik berupa kecintaan serta kebencian bisa saja terjadi dalam ranah yang sama. Iklan yang baik terlihat dari apakah pesan yang disampaikan 
olehnya tersampaikan dengan lugas dan jelas. Dalam kaca mata komunikasi politik, iklan adalah suatu cara untuk menyampaikan gagasan dan pemikiran kepada masyarakat. Maka iklan politik semestinya berisi visi dan program yang ditawarkan kepada masyarakat yang jika dipilih dan dipercaya untuk mengemban amanah dan kekuasaan, akan dijalankan dengan bijak.

Banyaknya iklan politik di media menunjukkan bahwa keinginan partai untuk memenangi pemilu sangat besar. Iklan di media massa sangat efektif dan efisien dalam menjangkau masyarakat banyak. Dan diperkuat dengan penerapan sistem pemilihan langsung yang mendorong para peserta pemilu maupun Pilkada sehingga parpol harus lebih gencar dalam menggalang suara dari pemilih. Dari iklan kampanye politik yang muncul sendiri pun tidak terlalu tampak perbedaan pesan yang ingin ditampilkan lewat iklan-iklan tersebut.

\section{Iklan Politik dan Pendidikan Politik Publik}

Iklan politik dalam kaitannya dengan perwujudan demokrasi dalam proses pendidikan politik kepada masyarakat adalah iklan politik tersebut apakah mampu memberikan hal yang positif. Iklan politik yang kebanyakan hanya menampilkan suatu realitas yang semu dikhawatirkan justeru memberikan hal yang berdampak negatif terhadap masyarakat. Seharusnya iklan politik harus mengemukakan realitas empiris. Sehingga tidak aneh kalau iklan politik kerap dikritik tajam karena muatannya yang justeru memperkeruh dan menyesatkan, terkadang bohong, menipu, tisak rasional dan banyak yang tidak berpijak pada kenyataan, menggunkan data-data yang hanya dibenarkan oleh kelompok tertentu atau kebenaran data-data yang masih diragukan tapi sudah langsung dilempar ke publik. Akhirnya iklan tidak mendorong untuk belajar atau mengerti, tetapi mengajak untuk berharap. Aspek lain yang dapat dibaca melalui iklan, peristiwa semu berubah menjadi kejadian sehari-hari berkat kepatuhan konsumen terhadap apa yang dikatakan iklan. Khalayak terbiasa dengan tipu-menipu dan validitas data yang palsu.

Realitas kandidat dalam iklan politik merupakan representasi dari realitas yang sebenarnya, maka kebenarannya tak bisa dikonfirmasi oleh publik. Komunitas seorang kandidat bisa memeriksa apakah iklan politik si kandidat sesuai dengan realitanya, karena mereka memiliki informasi tentang dua realitas itu. Dengan begitu, mereka bisa melakukan konfirmasi dengan cara membandingkan dua realitas ini, sehingga tahu seandainya iklan politik kandidat tidak sesuai kenyataannya. Publik media hanya tahu realitas sang kandidat dari iklan politik. Publik tidak dapat melakukan konfirmasi untuk membuktikan bahwa realitas dalam iklan politik merupakan representasi dari realitas sebenarnya si kandidat. Realitas kandidat dalam dalam iklan politik merupakan satu-satunya realitas, seperti citra apa yang hendak dibangun dalam iklan politik, itulah realitas yang diterima khalayak. 
Iklan politik yang ada agaknya sama-sama mengedepankan popularitas, lebih-lebih calon independent yang hanya dikenal dikalangan terbatas-kampus, lembaga survey. Dan mereka beriklan untuk menunjukkan diri mereka eksis atau ada. Meski demikian, pesan iklan politik tidak sekedar yang penting dikenal, tetapi popular dengan citra tertentu. Mereka beriklan untuk menyatakan eksistensi diri mereka.(Deddy Mulyana, 2007) Iklan kampanye politik di media massa mungkin menimbulkan kesan terbiasa (familiarity) akan sosok yang diangkat. Karena orang yang paling bayak menerima pesan adalah orang yang cenderugan untuk tahu.(Dan Nimmo, 2006)

Menurut Deddy Mulyana Iklan politik di media massa sifatnya memang satu arah dan layaknya produksi di media massa, iklan politik dibentuk sedemikian rupa untuk menampilkan pencitraan kandidat dengan narasi dan ilustrasi yang dibuat secara menarik dan seolah-olah dekat dengan masyarakat yang juga diikutsertakan dalam iklan kampanye politik tersebut serta peduli dengan isu-isu yang dijadikan andalan.

Iklan politik diharapkan sebagai wahana pendidikan politik dengan menyodorkan serangkai pedoman kebijakan. Bukan sekedar slogan dan pernyataan serampangan semata. Iklan semestinya mencerdaskan dan mengundang rasa simpatik. Iklan tentu saja dibutuhkan sebagai media komunikasi antara partai dengan rakyat. Iklan politik merupakan bahagian dari kampanye. Namun iklan dimaksud hendaknya ditata dengan bijak, terkait dengan visi dan misi partai berikut kandidatnya. Sebab siapa yang memiliki visi yang jelas, serta dibarengi dengan program-program yang rasional akan mendapat dukungan dari khalayak.

\section{Simpulan}

Peralihan sistem politik di Indonesia dari sistem yang otoritarianisme ke sistem demokrasi membuat persaingan untuk merebut suara dari para pemilih semakin bebas dan terbuka. Anggota partai politik dan perseorangan yang akan mencalonkan diri sebagai anggota legislatif melakukan segala upaya untuk meraih simpati para pemilih. Kampanye konvensional, seperti rapat akbar dan arakarakan mulai ditinggalkan para kontestan. Iklan melalui semua lini cetak dan elektronik termasuk internet kemudian dilirik sebagai cara yang dianggap mampu menggantikannya. Kontestan mulai menggunakan jasa profesional perusahaan periklanan untuk membuat iklan yang dapat membujuk pemilih, terutama pemilih yang belum menentukan sikap.

Akan tetapi yang terjadi dari pemilu ke pemilu di era reformasi ini, iklan politik yang muncul tidak beranjak dari materi yang mengedepankan penggambaran sosok, figur seseorang yang digambarkan sebagai pemimpin. Baik pemimpin partai politik, maupun tokoh yang akan maju mencalonkan diri sebagai calon presiden. Kemunculan iklan politik yang selalu menggambarkan sosok figur 
seseorang menarik diamati, mengingat banyak makna yang tersembunyi di balik iklan tersebut yang ingin disampaikan kepada khalayak, baik secara langsung maupun tidak.

Bagaimanapun juga iklan politik adalah sebuah produk media, sebagai sebuah produk yang notabene merupakan hasil rekonstruksi dari realitas, publik akan menikmati hasil konstruksi realitas yang sudah merupakan cermin yang tak selalu bening bahkan terkadang pecah dan memantulkan sudut-sudut lain yang berbeda jauh dari aslinya. Jadi sebenarnya realitas sosial itu nisbi yang muncul dalam produk media itu adalah realitas media. Dari sini hendaknya kemudian menjadi tugas bagi pihak-pihak media atau publikasi lainnya dalam memproduksi pesan atau bermacam kontennya agar berusaha obyektif, bijak, berimbang tidak memihak, mencerdaskan dan sejalan dengan normal aturan semisal etika pers jurnalistik.

\section{Referensi}

Buku dan Jurnal :

DN, Susilastuti. 'Kebebasan Pers Masa Orde Baru'. dalam Jurnal Ilmu Sosial dan Politik UGM Vol. 4 No. 2 Nopember. Jogjakarta: UGM Press. 2000.

Kasali, Rhenal. Manajemen Periklanan: Konsep dan Aplikasinya di Indonesia. Jakarta: PT Pustaka Utama Graffiti. 1995.

Manan, Bagir. Politik Publik Pers. Jakarta: Dewan Pers. 2012

McLeod, Jack M., Gerald M. Kosicki and Douglas M. Mc Leod. The Expanding Boundaries of Political Communication Effects. UK: Lauwrence Erlbaum Associates. 1994.

McQuail, Dennis. Mass Communication Theory. London: Sage Publications. 2000.

Mulyana, Deddy. Ilmu Komunikasi Suatu Pengantar. Bandung: Rosda Karya. 2007.

Muzayyad, Idy - Komisioner KPI Pusat. 'Bebas tidak Bablas'. dalam Surat Kabar Republika 13 Pebruari 2012.

Nimmo, Dan. Komunikasi Politik. Bandung: Rosda Karya. 2006.

Sudiana. Komunikasi Periklanan Cetak. Bandung: Remadja Karya. 1986.

Tubbs, S. L. dan Moss S. Human Communication: Principles and Contexts. New York: McGraw Hill. 2003.

Wahyuni, Hermin Indah. 'Relasi Media - Negara - masyarakat dan Pasar..'. dalam Jurnal Ilmu Sosial dan Politik UGM Vol. 4 No. 2 Nopember. Jogjakarta: Ugm Press 2000

\section{Internet:}

Gayatri, Gati. Efek Iklan Politik Dalam Media Massa Terhadap Perilaku Memilih Dalam Pemilu. dalam website: http://balitbang.depkominfo.go.id/addfile/jurnal/Jurnal\%2oprofesi/Jurnal\%2045/E FEK\%2OIKLAN\%2OPOLITIK\%2ODALAM\%2OMEDIA\%2OMASSA\%2O\%20\%2oGati\%2oke\%202.doc.

Mongilala, Andika. Teori Marketing Politik dalam Website: http://webandikamongilala.wordpress.com/teori-marketing-politik/.

Rojak, Abdul. Iklan Politik, Pembodohan Kepada Rakyat. dalam website : http://www.berpolitik.com/static/myposting/o8/myposting_1567o.html. 